\title{
Theoretical Determination of Forming Limit Diagram for Al 2024 T3 sheet when changing strain paths
}

\author{
Waleed J.Ali
}

\section{Mechanical Engineering Department, Mosul University}

\author{
Anas.O.Balod
}

\section{Abstract}

The effect of changing strain paths on forming limit curve of aluminum alloy $\mathrm{Al}$ $2024 \mathrm{~T} 3$ sheet has been studied by determining forming limit diagrams after prestraining theoretically. The method of calculating the shape of forming limit diagrams used Hosford yield criterion (high exponent) with the Marciniak and Kuczynski (M-K) analysis to include the effects of changing the strain path to several levels in (uniaxial, biaxial, and plane strain tension).In this work it was found that theoretical forming limit curve, calculated using the above analysis and yield function is closed to the experimental curve of complex strain path.

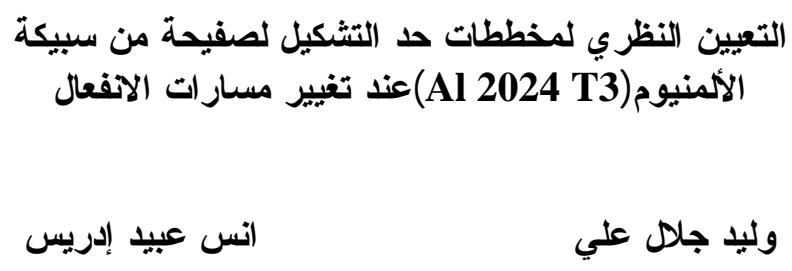

تمت در اسة تأثثر تغيير مسار ات الانفعال في منحني حد التشكيل لصفيحة من سبيكة الألمنيوم (Al 2024 T3) وذلكاصك

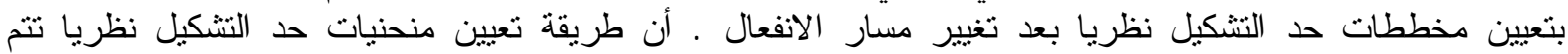

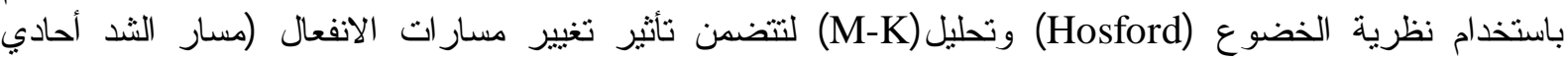

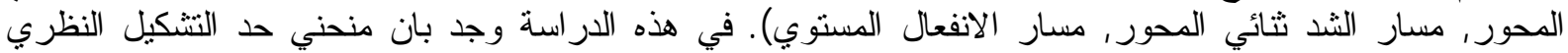
و المعيين باستخدام التحليل ونظرية الخضو ع أعلاه قريب من المنحني المعين عمليا بإتباع مسار ات اتفين انفعال معقد.

Keywords : sheet metal forming, forming limit diagram(FLD), complex strain path 